\title{
EFFECTIVENESS OF EXOGENOUS DIGESTIVE ENZYMES SUPPLEMENTATION ON THE PERFORMANCE OF RABBITFISH (Siganus rivulatus)
}

\author{
Mahmoud A. O. Dawood ${ }^{1 *}$, Mohamed Mohsen ${ }^{1}$, Ashraf El-dakar ${ }^{2}$, Elsaid Abdelraouf ${ }^{1}$, \\ Eman M. Moustafa ${ }^{3}$, Hamada A. Ahmed ${ }^{4}$
}

${ }^{1}$ Animal Production Department, Faculty of Agriculture, Kafrelsheikh University, 33516 Kafrelsheikh, Egypt, ${ }^{2}$ Aquaculture Department, Faculty of Fish Resources, El-Arish, Suez University, Egypt, ${ }^{3}$ Department of Fish Diseases and Management, Faculty of Veterinary Medicine, Kafrelsheikh University, 33516, Kafrelsheikh, Egypt, ${ }^{4}$ Department of Nutrition and Veterinary Clinical Nutrition, Faculty of Veterinary Medicine, Damanhour University, Damanhour, Egypt

*Corresponding author, E-mail: mahmouddawood55@gmail.com

\begin{abstract}
The current study was established to test the possibility of using exogenous digestive enzymes (EDE) in rabbitfish (Siganus rivulatus) diets. Five experimental diets containing 34\% soybean meal were prepared and supplemented with EDE at 0, 1, 2, 3, and $4 \mathrm{~g} \mathrm{~kg}^{-1}$ diet. Fish with average initial weight $( \pm 1.1 \mathrm{~g})$ were fed the test diets for 74 days. Rabbitfish offered the diets with EDE supplements exhibited significantly $(P<0.05)$ higher growth performance, feed intake, protein efficiency ratio, protein gain, and protein retention over the basal diet. But, no significant $(P>0.05)$ differences were observed in carcass composition and somatic parameters index with EDE supplementation. The physiological condition of fish fed diets with EDE showed that the hematocrit (\%), total plasma protein and total plasma globulin were significantly $(P<0.05)$ higher in fish fed EDE than the control group. It can be concluded that the addition of EDE in rabbitfish diets improved the growth performance, feed efficiency and health condition.
\end{abstract}

Key words: blood parameters; exogenous digestive enzymes; feed efficiency; growth; rabbitfish

\section{Introduction}

Aquaculture is one of the most economically important food sectors, representing the cheapest animal protein source for the increased population around the globe (1). Aquafeeds is contributing by around 70 to $80 \%$ from the total cost of the fish aquaculture (2). Thus, high quality feeds with balanced composition should be formulated to present the nutritional requirement and welfare for aquatic animals (3).

Fish meal has been served as the major protein source in aquafeed of carnivorous fish which tend to possess higher dietary protein requirements than omnivorous and herbivorous due to its balanced amino acid profile and palatability (4-7). However, the resource shortages and rising price of fish meal seriously restrict the use of fish meal in aquaculture. In 
this light, much efforts have been conducted to seek the sustainable supplies of protein sources to substitute fish meal. The plant protein sources have been limited used due to their relative low protein content and palatability, the presence of anti-nutritional factors and unbalanced amino acids profiles $(4,8,10,11)$. Digestive enzymes are helping in the food digestion process by transforming the nondigestible ingredients into more absorbable nutrients (9). Using of digestive enzymes is also recommended to facilitate the digestion process of fibrous ingredients existed in plant proteins such as: starch, cellulose and protein into simpler substances (3). Amylases, lipases, cellulases, xylanases, phytases and proteases are different forms of exogenous digestive enzymes which has been applied successfully in animal nutrition and aquafeed $(10,11)$. Since specific enzyme preparations have become valuable tools for economically manipulating digestive processes in animals (12), there are also considerable interests in using enzymes as supplements in fish feeds $(3,9,13)$.

Rabbitfish species have long been identified as appropriate candidates for aquaculture in the Indo-Pacific and the Middle East area (14). Although they are herbivorous and could potentially be fed soy bean meal-based diets, non-fish meal feeds might reduce the digestibility and assimilation of this species. Under the circumstances, fish diets should be supplemented by using digestive enzymes to further utilize the prepared feeds efficiently (13, 15, 16).

The present study was performed to examine the possibility of using exogenous digestive enzymes "cellulases, xylanases, $\alpha$-amylase and proteases mixture" on growth, feed efficiency, carcass composition and health condition of rabbitfish (Siganus rivulatus).

\section{Materials and methods}

\section{Experimental system}

Rabbitfish (S. rivulatus) juveniles were obtained from the coast of Mediterranean Sea, El-Arish, Egypt. The collected fish were carried carefully in well prepared tanks to the "Mariculture Research Center, Faculty of
Environmental Agricultural Sciences, Suez Canal University, El-Arish, Egypt", then acclimatized for 1 week before starting the trial. A total of 150 fish were distributed in 15 glass aquaria (50 1) where each aquarium was stocked with 10 fish with similar size (initial weight 1.1 g). The trial was conducted in triplicates. Each aquarium was provided with submerged air diffusers for aeration and about 30-35\% of water was changed daily. The water quality parameters were measured daily and remained at $34 \mathrm{~g} \mathrm{~kg}^{-1}, 25 \pm 1^{\circ} \mathrm{C}, 8.9$ and $7 \mathrm{mg} \mathrm{kg}^{-1}$, for salinity, temperature, $\mathrm{pH}$ and $\mathrm{DO}$, respectively.

\section{Diet preparation}

The basal diet $(32.2 \%$ crude protein and $8.5 \%$ lipids) was supplemented with exogenous digestive enzymes (EDE) $\left(\mathrm{ZADO}^{\circledR}\right.$, patent No. 22155 of Egypt) at $0,1,2,3$ and $4 \mathrm{~g} \mathrm{~kg}^{-1}$. The basal diet was prepared to contain fish meal $(65 \%)$ and soybean meal $(45 \%)$ as protein sources and other ingredients were added by following El-Dakar et al. (13) (Table 1). The pellets size was $1.5-\mathrm{mm}$ die. Pellets were air dried and stored at $-20^{\circ} \mathrm{C}$. Each diet was offered to three randomly chosen aquaria at $2-3 \%$ of biomass daily at 8.00, 12.00 and $16.00 \mathrm{~h}$ for 74 days. Fish were weighed at 2 -week intervals and ration was adjusted according to new fish weight per cage.

\section{Sample collection and analysis}

After 74 days, all fish in each aquarium were weighed, counted and total length was measured to calculate the specific growth rate (SGR), feed conversion ratio (FCR), protein efficiency ratio (PER), protein gain (PG), protein retention (PR), survival and condition factor $(\mathrm{CF})$ using the following formulae:

$\mathrm{SGR}=100 *(\ln \mathrm{FBW}-\ln \mathrm{IBW}) / \mathrm{t}, \mathrm{FCR}=\mathrm{FI}$ $(\mathrm{g}) / \mathrm{WG}(\mathrm{g})$, PER $=\mathrm{WG} /$ protein intake, $\mathrm{PG}=$ $\{(\mathrm{FBW}(\mathrm{g}) \times$ final whole-body protein content $(\%) / 100)-(\mathrm{IBW}(\mathrm{g}) \times$ initial whole-body protein content $(\%) / 100)\} /(\mathrm{WG}(\mathrm{g})) \times 1000$, $\mathrm{PR}=\left(\right.$ protein gain $\left.\left(\mathrm{g} \mathrm{kg} \mathrm{WG}^{-1}\right) \times 100\right) /$ protein intake $\left(\mathrm{g} \mathrm{kg} \mathrm{WG}^{-1}\right), \mathrm{CF}=100 *$ [body weight $(\mathrm{g}) /$ length $\left.^{3} \quad(\mathrm{~cm})\right]$ and survival= (final number/initial number)*100. Where FBW is final body weight $(\mathrm{g})$, IBW is initial body 
weight $(\mathrm{g})$, WG is weight gain, FI is feed intake (g) and $\mathrm{t}$ is 74 days.

Fish for initial carcass composition and diet samples were taken at the beginning of the trial and stored at $-20{ }^{\circ} \mathrm{C}$ until analysis. 3 fish were randomly taken from each aquarium and killed, then the liver was dissected and weighed to calculate the hepatosomatic index (HSI) where HSI $=100 *$ (liver weight/body weight).

Three fish from each aquarium were collected, pooled and stored at $-20{ }^{\circ} \mathrm{C}$ for carcass analysis. Using heparinized syringes, blood was collected from the caudal vein of 3 fish in each replicate aquarium and pooled. A small fraction of the heparinized blood was used to analyze the hematocrit and hemoglobin levels. Plasma samples were obtained by centrifugation at $3000 \times \mathrm{g}$ for $15 \mathrm{~min}$ using a high-speed refrigerated micro centrifuge and kept at $-20^{\circ} \mathrm{C}$. Hematocrit was determined by using micro hematocrit-heparinized capillary tubes and a micro hematocrit centrifuge $(10,000$ $\mathrm{g}$ for $10 \mathrm{~min}$.) (17). Hemoglobin concentrations were determined by the cyan hemoglobin method, at $540 \mathrm{~nm}$. Total plasma protein and albumin were determined using commercial kits produced by Pasteur labs (Egypt). However, the total plasma globulin was calculated by subtracting the total plasma protein from total plasma albumin according to Coles (18). Chemical analysis of feed and fish were performed according to the methods described in AOAC (19).

\section{Statistical analysis}

Data were analyzed using one-way analysis of variance (Package Super-ANOVA 1.11, Abacus Concepts, Berkeley, California, USA). Significance differences between means were evaluated using Duncan's new multiple range test at a probability level of 0.05 when t-test was significant.

\section{Results}

\section{Growth, survival and feed efficiency}

Survival rate of all fish groups fed varied levels of EDE ranged between 90 to $100 \%$. Using of EDE resulted in improved FBW, WG and SGR significantly $(P<0.05)$ than the control. Group 4 which supplemented with $3 \mathrm{~g}$ $\mathrm{kg}^{-1}$ EDE recorded the highest FBW and WG significantly $(P<0.05)$ than other groups. Fish gained $2025 \%, 2181,2307,2453$ and $2212 \%$ of their initial weight for the control, 1, 2, 3 and 4 $\mathrm{g} \mathrm{kg}^{-1}$ groups than their weights at the start of the experiment (Table 2).

Feed efficiency (FI, PG, and PR) of fish fed EDE is presented in Table 2. Results showed that rabbitfish fed diet contains different levels of EDE gave higher values significantly $(P<0.05)$ than EDE free group. Moreover, those fed $3 \mathrm{~g} \mathrm{~kg}^{-1}$ EDE gave significantly the higher values than the other groups $(P<0.05)$. Although, FCR recorded no significant differences $(P>0.05)$ among all experimental groups, rabbitfish fed $3 \mathrm{~g} \mathrm{~kg}^{-1}$ recorded the lowest value numerically comparing the other experimental groups. PER of fish fed diets supplemented with EDE at 1, 2, and $3 \mathrm{~g} \mathrm{~kg}^{-1}$ was significantly $(P<0.05)$ higher than the nonsupplemented group.

\section{Carcass composition}

No significant differences $(P>0.05)$ were observed in the analyzed carcass compositions for fish collected at the end of the trial in comparison with the values before the feeding trial (Table 3). Further, no difference was detected in $\mathrm{CF}$ and HSI values of fish fed different test diets (Table 3).

\section{Blood parameters}

Hematological parameters were presented in Figure 1A; hematocrit of rabbitfish was significantly $(P<0.05)$ improved in fish fed either 3 or $4 \mathrm{~g} \mathrm{~kg}^{-1}$ EDE than the other experimental diets. Although, hemoglobin value was not affected by EDE supplementation among tested groups, diets supplemented with 3 and $4 \mathrm{~g} \mathrm{~kg}^{-1}$ EDE recorded higher hemoglobin value significantly $(P<0.05)$ than the EDE free group (Fig. 1B).

Blood chemical parameters in rabbitfish were presented in Figure 2. Fish fed diets with EDE had significantly $(P<0.05)$ higher levels of total plasma protein compared to fish fed EDE free diet (Fig. 2A). Total plasma albumin recorded the lowest value significantly 
$(P<0.05)$ in fish fed $2 \mathrm{~g} \mathrm{~kg}^{-1} \mathrm{EDE}$ among the plasma globulin significantly $(P<0.05)$ than other experimental groups (Fig. 2B). Fish fed other experimental groups (Fig. 2C).

$\mathrm{EDE}$ at 2, 3, and $4 \mathrm{~g} \mathrm{~kg}^{-1}$ recorded higher total

Table 1: Formulation and chemical proximate composition of the experimental diets $\left(\mathrm{g} \mathrm{kg}^{-1} \mathrm{dry}\right.$ weight basis).

\begin{tabular}{|c|c|c|c|c|c|}
\hline \multirow[t]{2}{*}{ Ingredients } & \multicolumn{5}{|c|}{ EDE supplementation level $\left(\mathrm{g} \mathrm{kg}^{-1}\right)$} \\
\hline & 0 & 1 & 2 & 3 & 4 \\
\hline Fish meal & 120 & 120 & 120 & 120 & 120 \\
\hline Soybean meal & 340 & 340 & 340 & 340 & 340 \\
\hline Wheat bran & 100 & 100 & 100 & 100 & 100 \\
\hline Wheat milling by product & 170 & 169 & 168 & 167 & 166 \\
\hline Corn starch & 50 & 50 & 50 & 50 & 50 \\
\hline Rice bran & 150 & 150 & 150 & 150 & 150 \\
\hline Oil mixture ${ }^{1}$ & 50 & 50 & 50 & 50 & 50 \\
\hline Vitamin and mineral premix ${ }^{2}$ & 20 & 20 & 20 & 20 & 20 \\
\hline Digestive enzyme mixture $^{3}$ & 0 & 1 & 2 & 3 & 4 \\
\hline Total & 1000 & 1000 & 1000 & 1000 & 1000 \\
\hline \multicolumn{6}{|c|}{ Proximate composition and energy content (\% dry matter basis) } \\
\hline Crude protein & 32.9 & 31.5 & 31.8 & 32.5 & 32.2 \\
\hline Crude lipid & 9.7 & 7.3 & 7.5 & 8.3 & 8.8 \\
\hline Crude fiber & 2.5 & 2.5 & 2.3 & 2.4 & 2.4 \\
\hline Crude ash & 9.8 & 8.5 & 9 & 9 & 8.6 \\
\hline Nitrogen free extract & 45.1 & 50.2 & 49.4 & 47.8 & 48 \\
\hline $\mathrm{GE}\left(\mathrm{kJ} \mathrm{g}^{-1} \operatorname{diet}\right)^{4}$ & 19.34 & 19.00 & 19.01 & 19.19 & 19.35 \\
\hline $\mathrm{DE}\left(\mathrm{kJ} \mathrm{g}^{-1} \operatorname{diet}\right)^{5}$ & 16.69 & 16.41 & 16.40 & 16.55 & 16.72 \\
\hline $\mathrm{P} / \mathrm{E}$ ratio (mg CP kJ ${ }^{-1} \mathrm{DE}$ ) & 19.71 & 19.20 & 19.39 & 19.64 & 19.26 \\
\hline
\end{tabular}

${ }^{1}$ Mixture of Sunflower oil and linseed oil with a ratio of 1:1.

${ }^{2}$ Commercial Vitamin (Super Vit, Arab veterinary Industrial Co., Jordan). 15.000 IU vitamin A, $0.7 \mathrm{~g}$ vitamin C (Stay $\mathrm{C}^{\circledR}, 35 \%$ active), $15.000 \mathrm{IU}$ vitamin $\mathrm{D}_{3}, 2 \mathrm{mg}$ vitamin $\mathrm{E}, 2.5 \mathrm{mg}$ vitamin $\mathrm{B}_{2}, 2 \mathrm{mg}$ vitamin $\mathrm{K}_{3}, 10 \mathrm{mg}$ nicotineamide, $3 \mathrm{mg}$ vitamin $\mathrm{B}_{6}, 5 \mathrm{mg}$ vitamin $\mathrm{B}_{12}, 2 \mathrm{mg}$ vitamin $\mathrm{B}_{1}, 2 \mathrm{mg}$ folic acid, $5.5 \mathrm{mg}$ Ca-D-pantothenate, and mineral premix (Eco Vit, Egyptian veterinary produced and feed a additives Co., Demyatta, Egypt). $200 \mathrm{~g}$ calcium, $90 \mathrm{~g}$ phosphate, $40 \mathrm{~g}$ sodium, $2.5 \mathrm{~g}$ copper, $48 \mathrm{~g}$ magnesium, $3.6 \mathrm{~g}$ manganese, $23.5 \mathrm{~g}$ zinc, $8 \mathrm{~g}$ iron, $450 \mathrm{mg}$ cobalt, $200 \mathrm{mg}$ iodine and $20 \mathrm{mg}$ selenium.

${ }^{3}$ Exogenous digestive enzymes (EDE), ZADO ${ }^{\circledR}$ (enzymic preparation containing cellulases, xylanases, $\alpha$-amylase and proteases from anaerobic bacterium, patent No. 22155 of Egypt).

${ }^{4}$ Gross energy was calculated by using factors of $23.62,39.5$ and $17.56 \mathrm{~kJ} \mathrm{~g}^{-1}$ for protein, lipid and carbohydrate, respectively (20).

${ }^{5}$ Digestible energy content was estimated as $16.72,16.72$ and $37.62 \mathrm{~kJ} \mathrm{~g}^{-1}$ for protein, carbohydrate and lipid, respectively (21). 
Table 2: Growth performance, survival and feed efficiency utilization of rabbitfish fed diets supplemented with EDE for 74 days*

\begin{tabular}{llllll}
\hline Parameters & \multicolumn{5}{l}{ EDE supplementation level $\left(\mathrm{g} \mathrm{kg}^{-1}\right)$} \\
& 0 & 1 & 2 & 3 & \\
\cline { 2 - 6 } & & & & \\
\hline INW & $1.13 \pm 0.02$ & $1.14 \pm 0.01$ & $1.09 \pm 0.01$ & $1.1 \pm 0.03$ & $1.14 \pm 0.03$ \\
FBW & $24.01 \pm 0.07^{\mathrm{a}}$ & $26.01 \pm 0.46^{\mathrm{b}}$ & $26.24 \pm 0.17^{\mathrm{b}}$ & $28.07 \pm 0.19^{\mathrm{c}}$ & $26.41 \pm 0.35^{\mathrm{b}}$ \\
WG (g) & $22.88 \pm 0.07^{\mathrm{a}}$ & $24.87 \pm 0.46^{\mathrm{b}}$ & $25.15 \pm 0.18^{\mathrm{b}}$ & $26.97 \pm 0.21^{\mathrm{c}}$ & $25.26 \pm 0.36^{\mathrm{b}}$ \\
WG (\%) & $2025.42 \pm 31^{\mathrm{a}}$ & $2181.12 \pm 33.6^{\mathrm{b}}$ & $2307.29 \pm 26.6^{\mathrm{bc}}$ & $2453.55 \pm 56^{\mathrm{c}}$ & $2212.88 \pm 71.7^{\mathrm{b}}$ \\
SGR (\%) & $4.13 \pm 0.02^{\mathrm{a}}$ & $4.23 \pm 0.02^{\mathrm{b}}$ & $4.3 \pm 0.02^{\mathrm{bc}}$ & $4.38 \pm 0.03^{\mathrm{c}}$ & $4.24 \pm 0.04^{\mathrm{b}}$ \\
Survival $(\%)$ & 100 & 95 & 90 & 100 & 95 \\
FI & $55.01 \pm 0.29^{\mathrm{a}}$ & $59.25 \pm 0.14^{\mathrm{b}}$ & $59.38 \pm 0.28^{\mathrm{b}}$ & $62.26 \pm 0.09^{\mathrm{c}}$ & $59.76 \pm 0.32^{\mathrm{b}}$ \\
FCR & $2.4 \pm 0.01$ & $2.38 \pm 0.05$ & $2.36 \pm 0.02$ & $2.31 \pm 0.02$ & $2.37 \pm 0.04$ \\
PER & $1.26 \pm 0.01^{\mathrm{a}}$ & $1.34 \pm 0.03^{\mathrm{b}}$ & $1.33 \pm 0.01^{\mathrm{b}}$ & $1.33 \pm 0.1^{\mathrm{b}}$ & $1.31 \pm 0.02^{\mathrm{ab}}$ \\
PG & $142.18 \pm 0.00^{\mathrm{a}}$ & $146.41 \pm 0.01^{\mathrm{b}}$ & $147.04 \pm 0.04^{\mathrm{c}}$ & $147.52 \pm 0.01^{\mathrm{d}}$ & $146.45 \pm 0.08^{\mathrm{b}}$ \\
PR & $25.73 \pm 0.14^{\mathrm{a}}$ & $27.33 \pm 0.07^{\mathrm{b}}$ & $27.76 \pm 0.13^{\mathrm{c}}$ & $29.85 \pm 0.05^{\mathrm{e}}$ & $28.18 \pm 0.17^{\mathrm{d}}$ \\
\hline
\end{tabular}

*Values are means of triplicate groups' \pm S.E.M. Within a row, means with different alphabet are significantly different $(P<0.05)$, means with the same letters are not significantly different $(P>0.05)$. Absence of letters indicates no significant difference between treatments.

Table 3: Whole body proximate analysis (\%) and somatic parameters of rabbitfish fed diets supplemented with EDE for 74 days* EDE supplementation level $\left(\mathrm{g} \mathrm{kg}^{-1}\right)$

\begin{tabular}{llllll}
\hline Initial fish & 0 & 1 & 2 & 3 & 4
\end{tabular}

\begin{tabular}{lllllll}
\hline Moisture & $70.89 \pm 0.65$ & $69 \pm 0.4$ & $69.6 \pm 0.32$ & $69.3 \pm 0.24$ & $69.6 \pm 0.06$ & $69.15 \pm 0.06$ \\
Crude protein & $14.18 \pm 0.15$ & $14.22 \pm 0.29$ & $14.62 \pm 0.21$ & $14.68 \pm 0.15$ & $14.73 \pm 0.1$ & $14.64 \pm 0.1$ \\
Crude lipid & $10.18 \pm 0.16$ & $11.06 \pm 0.22$ & $11.79 \pm 0.45$ & $11.81 \pm 0.47$ & $11.79 \pm 0.45$ & $11.46 \pm 0.75$ \\
Crude ash & $4.58 \pm 0.15$ & $4.62 \pm 0.15$ & $4.43 \pm 0.33$ & $4.22 \pm 0.34$ & $4.27 \pm 0.09$ & $4.67 \pm 0.09$ \\
$\mathrm{CF}^{3}$ & - & $1.98 \pm 0.04$ & $1.86 \pm 0.01$ & $1.82 \pm 0.07$ & $1.76 \pm 0.11$ & $1.93 \pm 0.03$ \\
$\mathrm{HSI}^{4}$ & - & $1.39 \pm 0.09$ & $1.45 \pm 0.18$ & $1.65 \pm 0.09$ & $1.64 \pm 0.09$ & $1.54 \pm 0.07$ \\
\hline
\end{tabular}

${ }^{*}$ Values are means of triplicate groups \pm S.E.M. Within a row, Absence of letters indicates no significant difference between treatments, Initial values are not included in the statistical analysis. 
(A)

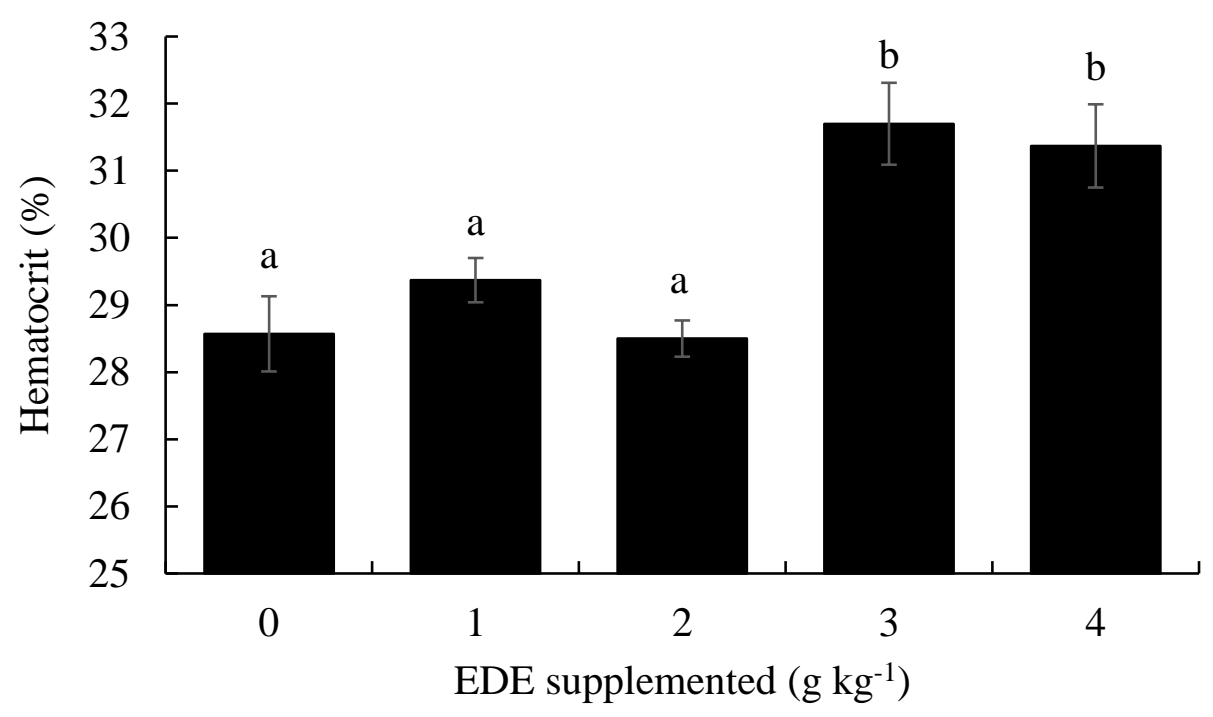

(B)

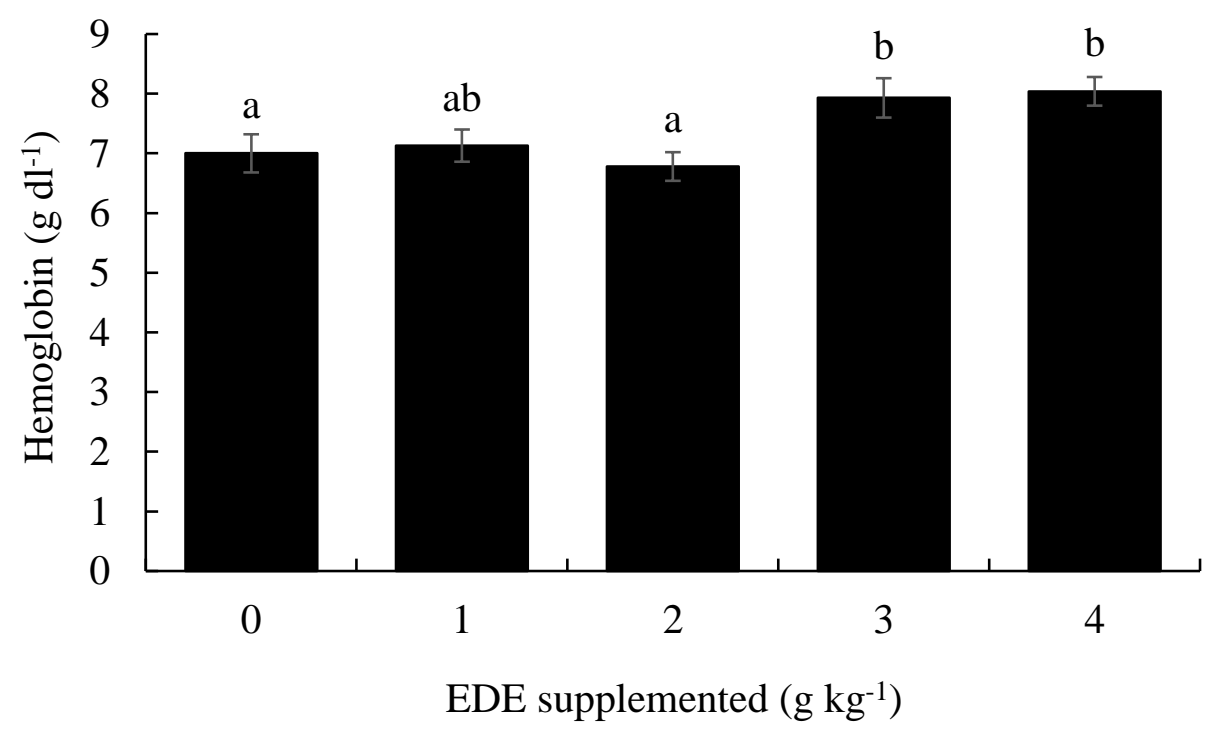

Figure 1: Average percentage of hematocrit (A) and hemoglobin values (B) in the blood of rabbitfish fed diets supplemented with different levels of EDE for 74 days. Values are means \pm pooled SEM from triplicate groups. Means with different alphabet are significantly different $(P<0.05)$ 
(A)

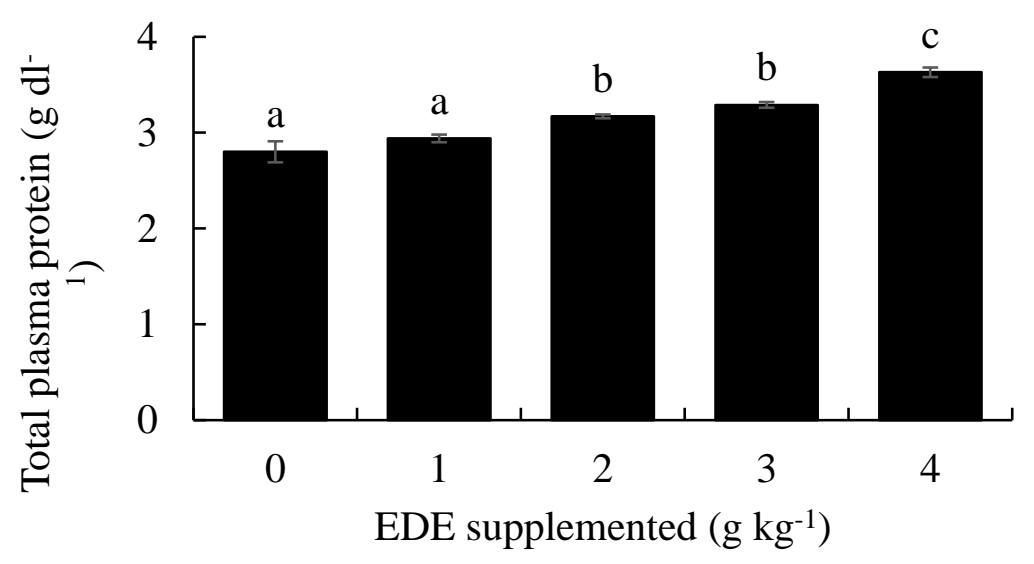

(B)

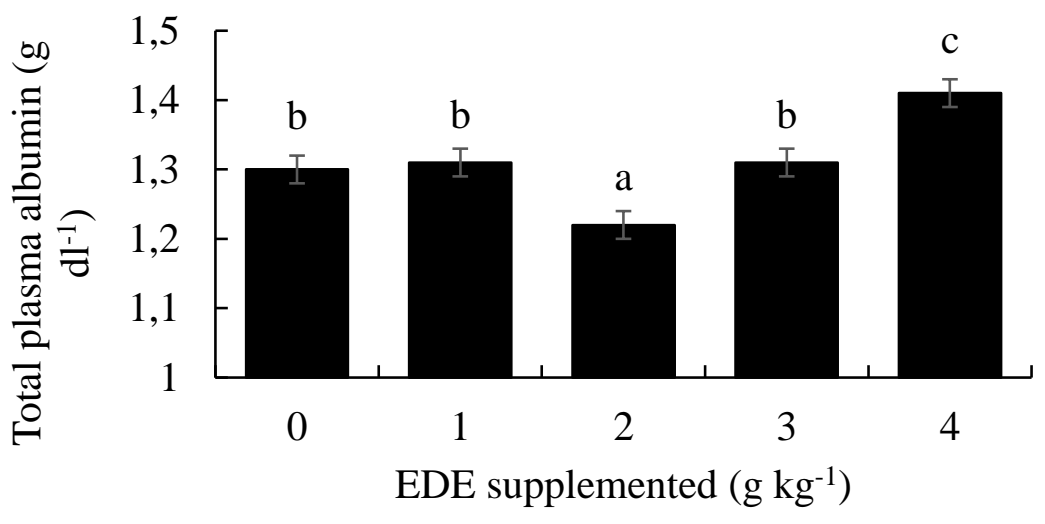

(C)

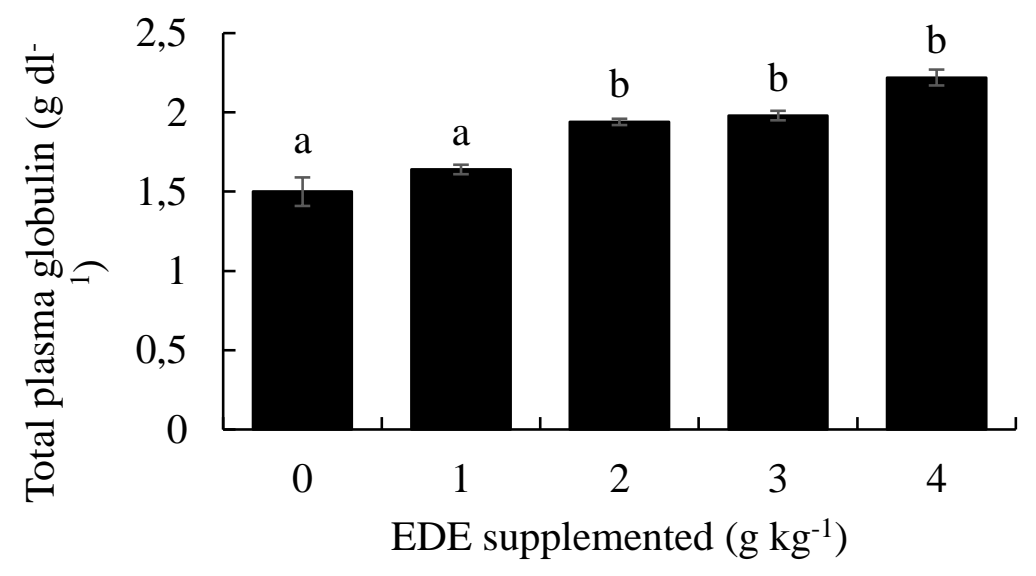

Figure 2: Average percentage of total plasma protein (A), total plasma albumin (B) and total plasma globulin (C) for rabbitfish fed diets supplemented with different levels of EDE for 74 days. Values are means \pm pooled SEM from triplicate groups. Means with different alphabet are significantly different $(P<0.05)$ 


\section{Discussion}

Nowadays, EDE are extensively used all over the world as additives in fish feeds to improve the nutritional value of diets, especially with the increase of plant proteins (22). In this study, FBW, survival, WG and SGR of fish fed diet containing $3 \mathrm{~g} \mathrm{~kg}^{-1}$ EDE were significantly improved. It means that the enzymatic treatment with EDE improved the digestion process to be more suitable for increasing anaerobic bacteria and exogenous enzymes activity. EDE was used as an exogenous enzyme extracted from anaerobic bacteria, would provide cellulases, xylanases, $\alpha$-amylase and proteases in fish feed. Diets containing EDE at level of $3 \mathrm{~g} \mathrm{~kg}^{-1}$ showed significantly higher SGR than other experimental diets. Similarly, the effects of dietary supplementation of exogenous enzymes increased the growth performance in several fish species including, Channel catfish $(23,24)$, Clarias catfish (25), Nile tilapia (26-28), Rainbow trout (29), and Common carp (30), respectively. However, Yigit and Keser (9) reported that, using of digestive enzymes in canola-based diets had no positive effect on the growth of Rainbow trout. The discrepancy with the present study was probably due to the differences in species and of plant protein meal used.

In the present study, EDE supplementation in rabbitfish feeds improved feed intake (FI). Fish fed diet containing $3 \mathrm{~g} \mathrm{~kg}^{-1}$ EDE showed increased FI (62.26 g per fish) compared to $55.01 \mathrm{~g}$ per fish in the control diet. These findings might be due to the action of EDE, which may be caused by better utilization of some dietary fibre. As a result, the growth rates improved when fish fed the diets containing dietary EDE, reflecting that the lowest FCR value was detected in case of presence EDE in diets at level of $3 \mathrm{~g} \mathrm{~kg}^{-1}$ EDE. In this connection, McAllister et al. (31) reported that proposed modes of action for direct-fed enzymes include "solubilisation of dietary fibre before ingestion, provision of readily fermentable substrate for micro-organisms and/or enhancement of microbial enzyme activity in the gut". Shalaby et al. (32) reported that rabbitfish could utilize efficiently carbohydrates in their feeds.

The results indicated that the diets with EDE improved PER, PG, and PR values. This may be ascribed to stimulating the digestion of the fibrous components by increasing the rate of fibre digestion. Singh et al. (30) reported that the protease enzyme can hydrolyses proteins to short peptides in food which in turn increased the protein digestibility in the gastrointestinal tract and accordingly enhance the feed efficiency and growth performance of fish (33). The enzyme efficiency can be affected by the level of inclusion and species of organism (31). Chakrabarti et al. (34) demonstrated that the amylase activity was enhanced when the formulation contains 13-25\% corn starch. Rabbitfish showed a strong activity of $\beta$ glucuronidase which is responsible about the digestion of carbohydrate $(35,36)$. Rainbow trout also exhibited increased levels of absorbed protein as a result of increasing the activity of amylase (37). The amylase activity is affected by several factors including: feeding habit, structural of the carbohydrate, temperature and season of rearing $(20,38)$. The activity of amylase enzyme is higher in herbivorous and omnivorous fish than the carnivores (36). However, use of EDE in fish feeds will need to be more investigated on the basis of feeding habits, fish size and dietary composition. It is suggested that smaller fish may give better results in growth rate when received EDE containing diets than bigger ones.

Body compositions of rabbitfish were not affected by dietary supplementations of EDE. The present work confirmed the results obtained by Lara-Flores et al. (39). They found that no differences were observed in the wholebody moisture, protein, lipid, and ash contents. On the other hand, Goda et al. (3) reported that Nile tilapia carcass protein, lipid, and ash contents were affected by EDE addition.

Results showed that the somatic indices (CF and HSI) were not affected by the inclusion of EDE in rabbitfish diets. Similar results were obtained by El-Dakar et al. (13) who reported that the HSI was not affected by EDE feeding. 
The CF of the fish fed EDE was lower than that of control, which gave a CF similar to fish fed EDE at $4 \mathrm{~g} \mathrm{~kg}^{-1}$. These results reflect the small differences in weight together with length of the harvested fish.

The general health status of fish can be evaluated by measuring the blood indices which reflect the physiological response of fish towards different feeding strategies (40-42). In this study, high values of hematocrit were observed in fish fed EDE. However, EDE-free group exhibited lower hematocrit levels, which may trigger anaemia in fish (3). Results of the present study also revealed that all fish fed EDE gave higher levels of total plasma protein and total plasma globulin. This may be attributed to fast metabolism which in turn resulted in better total plasma protein and globulin contents.

\section{Conclusion}

In conclusion, our results showed that using of EDE for rabbitfish is recommended to enhance the growth, nutrient utilization and health condition. Improved performances were observed in fish fed diets supplemented with 3 $\mathrm{g} \mathrm{kg}^{-1} \mathrm{EDE}$ for 74 days.

\section{Acknowledgements}

The first author would like to acknowledge the head and staff of "the Mariculture Research Center, Faculty of Environmental Agricultural Sciences, Suez Canal University, El-Arish, North-Sinai, Egypt", for technical assistance throughout the course of the study and providing of fish. We are grateful to E.S.H. Lab., El-Arish, North-Sinai, Egypt members for their technical assistance during the blood analysis.

\section{Conflict of interest}

The authors declare that they have no conflict of interest.

\section{References}

1. Dawood MAO, Koshio S. Recent advances in the role of probiotics and prebiotics in carp aquaculture: a review. Aquaculture 2016; 454:24351.

2. Dawood MAO, El-Dakar A, Mohsen M, Abdelraouf E, Koshio S, Ishikawa M, Yokoyama S.
Effects of using exogenous digestive enzymes or natural enhancer mixture on growth, feed utilization, and body composition of Rabbitfish, Siganus rivulatus. Journal of Agricultural Science and Technology. B. 2014;4(3B).

3. Goda AM, Mabrouk HA, Wafa MA, El-Afifi TM. Effect of using baker's yeast and exogenous digestive enzymes as growth promoters on growth, feed utilization and hematological indices of Nile tilapia, Oreochromis niloticus fingerlings. Journal of Agricultural Science and Technology. B. 2012;2(1B).

4. Dawood MA, Koshio S, Ishikawa M, Yokoyama S. Effects of partial substitution of fish meal by soybean meal with or without heat-killed Lactobacillus plantarum (LP20) on growth performance, digestibility, and immune response of amberjack, Seriola dumerili juveniles. BioMed Res Int 2015;2015.

5. Dossou S, Koshio S, Ishikawa M, Yokoyama S, Dawood MAO, El Basuini MF, El-Hais AM, Olivier A. Effect of partial replacement of fish meal by fermented rapeseed meal on growth, immune response and oxidative condition of red sea bream juvenile, Pagrus major. Aquaculture 2018; 490:228-35.

6. Dossou S, Koshio S, Ishikawa M, Yokoyama S, Dawood MAO, El Basuini MF, Olivier A, Zaineldin AI. Growth performance, blood health, antioxidant status and immune response in red sea bream (Pagrus major) fed Aspergillus oryzae fermented rapeseed meal (RM-Koji). Fish Shellfish Immunol 2018; 75:253-62.

7. Dossou S, Koshio S, Ishikawa M, Yokoyama S, El Basuini MF, Zaineldin AI, Mzengereza K, Moss A, Dawood MAO. Effects of replacing fishmeal with fermented and non-fermented rapeseed meal on the growth, immune and antioxidant responses of red sea bream (Pagrus major). Aquacult Nutr 2019; https://online library.wiley.com/doi/abs/10.1111/anu.12876

8. Nordrum S, Bakke-McKellep AM, Krogdahl $\AA$, Buddington RK. Effects of soybean meal and salinity on intestinal transport of nutrients in Atlantic salmon (Salmo salar L.) and rainbow trout (Oncorhynchus mykiss). Comp Biochem Physiol B Biochem Mol Biol 2000; 125(3):317-35.

9. Yigit NO, Keser E. Effect of cellulase, phytase and pectinase supplementation on growth performance and nutrient digestibility of rainbow trout (Oncorhynchus mykiss, Walbaum 1792) fry fed diets containing canola meal. J Appl Ichthyol 2016;32(5):938-42. 
10. Feord JC. Exogenous enzymes improve performance of carp and tilapia when fed diets containing high levels of soybean meal, in: VII International Symposium on Nutrition and Feeding of Fish. 1996.

11. Forster I, Higgs DA, Dosanjh BS, Rowshandeli M, Parr J. Potential for dietary phytase to improve the nutritive value of canola protein concentrate and decrease phosphorus output in rainbow trout (Oncorhynchus mykiss) held in $11^{\circ} \mathrm{C}$ fresh water. Aquaculture 1999; 179(1-4):109-25.

12. Johnson R, Williams P, Campbell R. Use of enzymes in pig production. Proc. $1^{\text {st }}$ Symp. On Enzymes in Animal Nutrition (Ed. C. Wenk and M. Boessinger). 1993: 49-60.

13. El-Dakar AY, Shalaby SM, Saoud IP. Assessing the use of a dietary probiotic/prebiotic as an enhancer of spinefoot rabbitfish Siganus rivulatus survival and growth. Aquacult Nutr 2007;13(6):407-12.

14. Pillay TVR, Kutty MN. Aquaculture: Principles and Practices, $2^{\text {nd }}$ edn. Blackwell Publishing, Ames, IA, USA, pp 2005:458-60.

15. Dawood MAO, Koshio S, Abdel-Daim MM, Van Doan H. Probiotic application for sustainable aquaculture. Rev Aquacult 2018. https://onlinelibrary.wiley.com/doi/abs/10.1111/ra q. 12272

16. Dawood MAO, Koshio S, Esteban MÁ. Beneficial roles of feed additives as immunostimulants in aquaculture: a review. Rev Aquacult 2018; 10(4):950-74.

17. Dawood MAO, Koshio S, Ishikawa M, Yokoyama S. Effects of heat killed Lactobacillus plantarum (LP20) supplemental diets on growth performance, stress resistance and immune response of red sea bream, Pagrus major. Aquaculture 2015; 442:29-36.

18. Coles EH. Plasma Proteins, Veterinary Clinical Pathology, $2^{\text {nd }}$ ed., W. B. Saunders Co., London. pp. 1974:558-560.

19. AOAC. Official Methods of Analysis of Association of Official Analytical Chemists, $15^{\text {th }}$ edn. Published by the Association of Analytical Chemists, Arlington, VA, USA.1990.

20. NRC. Nutrition Requirements of Fish. National Academy Press, Washington, DC, USA. 1993.

21. Garling Jr DL, Wilson RP. Optimum dietary protein to energy ratio for channel catfish fingerlings, Ictalurus punctatus. J Nutr 1976; 106(9):1368-75.

22. Kolkovski S, Tandler A, Izquierdo MS. Effects of live food and dietary digestive enzymes on the efficiency of microdiets for seabass (Dicentrarchus labrax) larvae. Aquaculture 1997; 148(4):313-22.

23. Jackson LS, Li MH, Robinson EH. Use of Microbial Phytase in Channel Catfish Ictalurus punctatus Diets to Improve Utilization of Phytate Phosphorus 1. J World Aquacult Soc 1996; 27(3):309-13.

24. Debnath D, Sahu NP, Pal AK, Jain KK, Yengkokpam S, Mukherjee SC. Mineral status of Pangasius pangasius (Hamilton) fingerlings in relation to supplemental phytase: absorption, whole-body and bone mineral content. Aquacult Res 2005;36(4):326-35.

25. Giri SS, Sahoo SK, Sahu AK, Meher PK. Effect of dietary protein level on growth, survival, feed utilisation and body composition of hybrid Clarias catfish (Clarias batrachus $\times$ Clarias gariepinus). Animal Feed Sci Tech 2003;104(14):169-78.

26. Ali HM, Ghazalah AA, Gehad EA, Hammouda YA, Abo-State HA. Practical aspects and immune response of probiotics preparations supplemented to Nile tilapia (Oreochromis niloticus) diets. Nature \& Science 2010; 8:39-45.

27. El-Haroun ER, Goda AS, Kabir Chowdhury MA. Effect of dietary probiotic Biogen $^{\circledR}$ supplementation as a growth promoter on growth performance and feed utilization of Nile tilapia Oreochromis niloticus (L.). Aquacult Res 2006; 37(14):1473-80.

28. Lin S, Mai K, Tan B. Effects of exogenous enzyme supplementation in diets on growth and feed utilization in tilapia, Oreochromis niloticus x O. aureus. Aquacult Res 2007;38(15):1645-53.

29. Irianto A, Austin B. Use of probiotics to control furunculosis in rainbow trout, Oncorhynchus mykiss (Walbaum). J Fish Dis 2002;25(6):333-42.

30. Singh P, Maqsood S, Samoon MH, Phulia V, Danish M, Chalal RS. Exogenous supplementation of papain as growth promoter in diet of fingerlings of Cyprinus carpio. International Aquatic Research 2011; 3:1-9.

31. McAllister TA, Hristov AN, Beauchemin KA, Rode LM, Cheng, KJ. Enzymes in ruminant diets. In: Bedford, M., Partridge, G. (Eds.), Enzymes in Farm Animal Nutrition. CABI Publishing, Oxon, UK, 2001; 273-98.

32. Shalaby SM, El-Dakar AY, Ghoneim SI. Protein sparing effect by carbohydrate in diets of rabbitfish, Siganus rivulatus. Egyptian Journal of the Aquatic Biology and Fisheries 2001; 5:87-98. 
33. Wong MH, Tang LY, Kwok FS. The use of enzyme-digested soybean residue for feeding common carp. Biomedical and environmental sciences: BES. 1996;9(4):418-23.

34. Chakrabarti I, Gani MA, Chaki KK, Sur R, Misra KK. Digestive enzymes in 11 freshwater teleost fish species in relation to food habit and niche segregation. Comp Biochem Physiol A Mol Integr Physiol 1995 Sep; 112(1):167-77.

35. Moraes G, Bidinotto PM. Induced changes in the amylohydrolytic profile of the gut of Piaractus mesopotamicus (Holmberg, 1885) fed different levels of soluble carbohydrate: its correlation with metabolic aspects. Revista de Ictiologia. 2000;8(1/2):47-51.

36. Lundberg B, Lipkin Y. Natural food of the herbivorous rabbitfish (Siganus spp.) in northern Red Sea. Botanica Marina 1979; 22(3):173-82.

37. Kawai S. Studies on digestive enzymes of fishes-III. Development of digestive enzyme of rainbow trout after hatching and the effect of dietary change on the activities of digestive enzyme in the juvenile stage. Bull Jpn Soc Sci Fish 1973; 39:81927.

38. Sabapathy U, Teo LH. A quantitative study of some digestive enzymes in the rabbitfish, Siganus canaliculatus and the sea bass, Lates calcarifer. J Fish Biol 1993;42(4):595-602.
39. Lara-Flores M, Olvera-Novoa MA, GuzmánMéndez BE, López-Madrid W. Use of the bacteria Streptococcus faecium and Lactobacillus acidophilus, and the yeast Saccharomyces cerevisiae as growth promoters in Nile tilapia (Oreochromis niloticus). Aquaculture 2003;216(14):193-201.

40. Dawood MAO, Koshio S, Ishikawa M, Yokoyama S. Interaction effects of dietary supplementation of heat-killed Lactobacillus plantarum and $\beta$-glucan on growth performance, digestibility and immune response of juvenile red sea bream, Pagrus major. Fish Shellfish Immunol 2015; 45(1):33-42.

41. Dawood MAO, Koshio S, Ishikawa M, Yokoyama S. Immune responses and stress resistance in red sea bream, Pagrus major, after oral administration of heat-killed Lactobacillus plantarum and vitamin C. Fish Shellfish Immunol 2016;54:266-75.

42. Dawood MAO, Koshio S, Ishikawa M, Yokoyama S, El Basuini MF, Hossain MS, Nhu TH, Dossou S, Moss AS. Effects of dietary supplementation of Lactobacillus rhamnosus or/and Lactococcus lactis on the growth, gut microbiota and immune responses of red sea bream, Pagrus major. Fish Shellfish Immunol 2016; 49:275-85. 